\title{
Keefektifan Model Pembelajaran Kooperatif 'Tipe Examples Non Examples' terhadap Hasil Belajar Siswa SMA
}

\author{
Rapiahtul Hikmah \\ IAIN Syaikh Abdurrahman Siddik Bangka Belitung
}

\begin{tabular}{ll}
\hline \hline Infor Artikel : \\
\hline & \\
Diterima & $: 28$ April 2019 \\
Direvisi & $: 20$ Mei 2019 \\
Dipublish & $: 28$ Juni 2019
\end{tabular}

\begin{abstract}
ABSTRAK
Penelitian ini bertujuan untuk mengetahui efektivitas pembelajaran kooperatif tipe 'Examples Non Examples' berdasarkan hasil belajar siswa SMA Negeri 1 Galesong pada larutan elektrolit, larutan non elektrolit, dan reaksi redoks. Examples Non Examples adalah metode pembelajaran dengan menggunakan gambar yang disajikan sesuai dengan kilauan dari 'Examples Non Examples'. Subjek dalam penelitian ini adalah 33 siswa SMA Negeri 1 Galesong, tahun akademik 2013/2014. Data dikumpulkan dengan menggunakan hasil belajar siswa (post test). Hasil percobaan menunjukkan bahwa rata-rata hasil belajar siswa dengan menggunakan Examples Non Examples dalam pembelajaran kimia adalah 81,45\% dengan kelulusan kelas 87,87\%. Dapat disimpulkan bahwa efektivitas Examples Non Examples' dalam pembelajaran kimia adalah $72,03 \%$.
\end{abstract}

Kata Kunci :

Examples Non Examples

Efektifitas

Hasil Belajar Siswa

Keywords:

Examples Non Examples

Effectiveness

Students' Outcomes

\section{ABSTRACT}

This study aims to determine the effectiveness of cooperative learning 'Examples Non Examples' type based on students' learning outcomes of SMA Negeri 1 Galesong study on electrolyte solution, non electrolyte solution and reaction redox. Examples Non Examples is a method of learning by using an image that is presented in accordance with shine from the 'Examples and non examples'. The subject in this research was 33 students of SMA Negeri 1 Galesong, academic year 2013/2014. The data was collected by using the student outcomes (post test). The result of experiment showed that the average of student outcomes with use Examples Non Examples in chemistry learning was $81,45 \%$ with class pass was $87,87 \%$. It can be concluded that the effectiveness of 'Examples Non Examples' in chemistry learning is 72,03\%.

\section{Koresponden:}

Rapiahtul Hikmah,

Email: hikmahwahidpep.@gmail.com

\section{Pendahuluan}

Pada Era Globalisasi sekarang ini merupakan sebuah tantangan bagi bangsa Indonesia dalam dunia pendidikan untuk mencerdaskan anak bangsa Indonesia agar dapat bersaing pada era global seperti sekarang ini. Permasalahan pendidikan begitu menarik untuk dibahas dalam pengembangan mutu peserta didik (Tjalla, 2010).

Dalam hal ini permasalahan yang sering muncul dalam dunia pendidikan yaitu model-model yang digunakan oleh pendidik kurang sesuai dengan kondisi yang ada, kurangnya sarana pembelajaran yang ada di sekolah, banyaknya siswa dalam satu kelas sehingga pendidikan susah untuk mengontrol perkembangan peserta didik, kurangnya motivasi siswa dalam belajar dan banyak lagi hal-hal yang menjadi permasalahan dalam dunia pendidikan.

Langkah terbaru yang pemerintah lakukan saat ini yaitu melakukan revisi terhadap kurikulum yang ada di Indonesia. Kurikulum yang dilaksanakan saat ini yaitu kurikulum 2013 menekankan bahwa guru tidaklah menjadi satu-satunya sumber belajar (Teacher Centred Learning) melainkan siswa juga memiliki peran penting dalam keberhasilan proses pembelajaran dalam kelas (Student Centred Learning) (Ningrum, 2009).

Keberhasilan dalam proses pembelajaran akan tercapai ketika siswa dan guru memiliki kesiapan dalam proses pembelajaran. Hal ini dikarenakan dalam proses pembelajaran dibutuhkan interaksi yang baik antara siswa dan guru, sehingga orang tidak lagi berpandangan bahwa seorang guru adalah seorang yang serba tahu sedangkan siswa adalah seseorang yang serba tidak tahu. Bagaimanapun belajar merupakan suatu proses dua arah, dimana siswa memerlukan feedback dari pengajar dan begitupun sebaliknya agar diperoleh hasil belajar yang lebih efektif (Rusman, 2011). 
Didalam kenyataan cara atau metode mengajar atau teknik penyajiaan yang digunakan guru untuk menyampaikan informasi atau pesan lisan kepada siswa berbeda dengan cara yang ditempuh untuk memantapkan siswa dalam menguasai pengetahuan, keterampilan serta sikap. Metode yang digunakan untuk memotivasi siswa agar mampu menggunakan pengetahuannya untuk memecahkan masalah yang dihadapi ataupun untuk menjawab suatu pertanyaan akan berbeda dengan metode yang digunakan untuk mencapai tujuan pembelajaran, agar siswa mampu berpikir dan mengemukakan pendapatnya sendiri di dalam menghadapi segala masalah dalam proses belajar mengajar (Roestiyah, 2008).

Kimia merupakan salah satu bidang studi yang terdapat dalam kurikulum untuk Sekolah Menengah Atas (SMA) dan ikut serta memberikan manfaat terhadap pengembangan pembangunan nasional terutama dalam bidang ilmu dan teknologi. Pelajaran kimia tidak dapat dipisahkan dari ilmu pengetahuan alam yang mengkaji gejala alam secara ilmiah. Pengajaran bidang studi kimia tingkat SMA berdasarkan pada pemahaman konsep yang mendalam, prinsip, hukum, rumus-rumus dan teori kimia serta saling keterkaitannya dan penerapannya untuk menyelesaikan masalah sehingga meningkatkan tingkat pencapaian tujuan pembelajaran atau hasil belajar siswa (Hutabalian, 2014).

Untuk mencapai tujuan yang terdapat dalam kurikulum, dapat dikatakan dalam pembelajaran khususnya pembelajaran kimia diperlukan pemahaman atau penguasaan konsep, dimana antara konsep yang satu dengan yang lainnya saling berkaitan.

Dari hasil observasi di SMA Negeri 1 Galesong, diketahui kelas X2 berjumlah 10 kelas dengan jumlah siswa dalam setiap kelas yaitu 35 sampai 40 orang siswa. Hasil observasi dan wawancara terhadap beberapa siswa kelas X2 SMA Negeri 1 Galesong mengemukakan bahwa dalam proses pembelajarannya siswa susah memahami materi hal ini dikarenakan penjelasannya yang terlalu rumit untuk dimengerti dan bahasa yang digunakan terlalu tinggi untuk dipahami oleh siswa (Marsita, Priatmoko, \& Kusuma, 2010). Selain itu, dalam proses pembelajaran kimia yang sebagian besar adalah pemahaman konsep, dan dalam proses penyajian materinya hanya guru yang lebih dominan atau berperang aktif dalam proses belajar mengajar dan menggunakan satu model saja. Sedangkan kita ketahui untuk sekang ini banyak modelmodel yang bisa kita gunakan dalam proses belajar mengajar yang relevan dengan materi yang ingin disajikan. Oleh karena itu akan dilakukan penelitian dengan menggunakan model pembelajaran kooperatif tipe examples non examples. Padahal kita ketahui, siswa tidak hanya mempelajari satu pelajaran saja di sekolah melainkan berbagai macam mata pelajaran harus mereka ikuti dalam sehari. Hal inilah yang menjadi salah satu alasan mengapa siswa kurang termotivasi untuk belajar materi kimia.

Dari permasalahan diatas ini maka salah satu upaya yang dapat dilakukan untuk meningkatkan hasil belajar siswa dalam belajar kimia digunakan model pembelajaran kooperatif dengan menggunakan metode Examples Non Examples pada materi larutan elektrolit, non elektrolit dan reaksi redoks. Examples non examples adalah suatu penyajian materi dengan menggunakan gambar atau konsep yang diilustrasikan berupa contoh dan non contoh yang relevan dengan kompetensi dasar.

Materi pokok larutan elektrolit, non elektrolit dan reaksi redoks merupakan materi pokok yang dipelajari di kelas X semester genap. Materi pokok tersebut merupakan materi yang memiliki banyak konsep yang berbentuk gambar-gambar seperti lampu menyalah dan lampu tidak menyalah. Hal ini dapat menunjukkan larutan elektrolit dan non elektrolit, lampu menyala redup, terang dan tidak menyala. Hal ini dapat menunjukkan larutan elektrolit lemah, kuat dan non elektrolit memperlihatkan gambar peranan larutan elektrolit dan non elektrolit. Ilmu kimia sperti larutan garam, larutan oralit, dan pemberian konsep reaksi redoks dengan contoh dan non contoh (Patmawati, 2011). Gambar-gambar tersebut sangat menarik untuk divisualkan, sehingga materi "Larutan Elektrolit, Non Elektrolit dan reaksi redoks" cocok menggunakan model pembelajaran kooperatif tipe Examples Non Examples.

Menurut Saleh, Nursni dkk. (2012) menyatakan Kebaikan dari model pembelajaran kooperatif tipe Examples Non Examples adalah: (a) Siswa lebih kritis dalam menganalisa gambar atau media yang digunakan. (b) Siswa mengetahui aplikasi dari materi. (c) Siswa diberi kesempatan untuk mengemukakan pendapatnya. Sedangkan manfaat model pembelajaran kooperatif tipe Examples Non Examples antara lain: penyampaian materi pembelajaran dapat diseragamkan, proses pembelajaran menjadi jelas dan menarik, proses pembelajaran lebih interaktif, efesiensi dalam waktu dan tenaga serta dapat meningkatkan kualitas hasil belajar siswa (Yensy, 2012).

Berdasarkan hal-hal tersebut di atas, maka penulis tertarik untuk melakukan penelitian dengan judul "Keefektifan Model Pembelajaran kooperatif tipe Examples Non Examples terhadap Hasil Belajar Siswa Kelas X2 SMA Negeri 1 Galesong (Studi pada Materi Pokok Larutan Elektrolit, Non Elektrolit dan Reaksi Oksidasi Reduksi). 
Metode

Penelitian ini adalah penelitian kuantitatif, yaitu penelitian eksperimen dengan menggunakan analisa

T-Test di SPSS 16.00 for Windows. Penelitian eksperimen adalah penelitian yang

\section{Hasil dan Pembahasan}

1. Efektifitas model pembelajaran kooperatif tipe exampels non examples terhadap hasil belajar siswa SMA Negeri 1 Galesong

Berdasarkan penelitian yang telah dilakukan di SMA Negeri 1 Galesong, maka diperoleh data hasil belajar siswa kelas X2 SMA Negeri 1 Galesong pada materi pokok larutan elektrolit, non elektrolit dan reaksi oksidasi reduksi menggunakan Examples Non Examples dapat terlihat pada tabel 2 yaitu sebagai berikut :

Tabel 2.

Statistik Deskriptif Hasil Belajar Siswa Dengan

Pembelajaran Menggunakan "Examples Non Examples"

\begin{tabular}{cc}
\hline Statistik & Nilai Statistik \\
\hline Jumlah Sampel & 33 \\
\hline Nilai Ideal & 100 \\
\hline Nilai Terendah & 52 \\
\hline Nilai Tertinggi & 92 \\
\hline Nilai Rata-rata (X) & 81,45 \\
\hline Efektivitas Pembelajaran & $72,03 \%$ \\
\hline Standar Deviasi (Sd) & 9,06
\end{tabular}

Dari tabel 2 menunjukkan bahwa dalam pembelajaran dengan menggunakan model pembelajaran kooperatif tipe Examples Non Examples, diperoleh nilai tertinggi 92, nilai terendah sebesar 52, nilai ideal sebesar 100 dengan jumlah siswa sebanyak 33 orang. Jika hasil belajar siswa dikelompokkan berdasarkan kriteria nilai ketuntasan hasil belajar siswa dalam bidang studi kimia di kelas X2 SMA Negeri 1 Galesong, maka diperoleh distribusi tingkat ketuntasan perorangan seperti pada Tabel 3.

Tabel 3.

Ketuntasan Hasil Belajar Siswa Kelas X2 SMA Negeri 1 Galesong

\begin{tabular}{|c|c|c|c|c|}
\hline No & \multicolumn{2}{|c|}{ Kategori } & Frekuensi & Persentase \\
\hline 1 & Tidak tuntas & $<70$ & 4 & 12,12 \\
\hline 2 & Tuntas & $\geq 70$ & 29 & 87,87 \\
\hline
\end{tabular}

Dari Tabel 2 menunjukkan bahwa dari 33 siswa yang mengikuti tes hasil belajar pada materi pokok larutan elektrolit, non elektrolit dan reaksi oksidasi reduksi terdapat 29 siswa atau 87,87\% yang tuntas dan tidak tuntas sebanyak 4 siswa dengan persentase $12,12 \%$ dan tuntas kelas yaitu $87,87 \%$. Selanjutnya, untuk melihat pencapaian indikator siswa melalui pembelajaran kooperatif tipe Examples Non Examples di kelas X2 SMA Negeri 1 Galesong, maka hasilnya dapat dilihat pada Tabel 4. 
Tabel 4.

Frekuensi dan Persentase Pencapaian Tiap Indikator Siswa Kelas X2 SMA Negeri 1 Galesong Dengan Menggunakan pembelajaran kooperatif tipe "Examples Non Examples"

\begin{tabular}{cccc}
\hline Indikator & $\begin{array}{c}\text { Frekuensi Siswa } \\
\text { Yang Tuntas }\end{array}$ & $\begin{array}{c}\text { Persentase (\%) } \\
\text { Ketuntasan }\end{array}$ & Kategori \\
\hline 1 & 24 & 72,72 & Efektif \\
\hline 2 & 23 & 69,69 & Efektif \\
\hline 3 & 23 & 69,69 & Efektif \\
\hline 4 & 25 & 75,75 & Efektif \\
\hline 5 & 22 & 66,66 & Efektif \\
\hline 6 & 26 & 78,78 & Efektif \\
\hline 7 & 23 & 69,69 & Efektif \\
\hline 8 & 21 & 63,63 & Efektif \\
\hline 9 & 22 & 66,66 & Efektif \\
\hline Rata-rata & 23,22 & 70,36 & \\
\hline
\end{tabular}

Berdasarkan tabel 4, untuk menentukan keefektifan model pembelajaran kooperatif tipe Examples Non Examples dapat dilihat dari rata-rata presentase pencapaian tiap indikator.

Selain tabel Frekuensi dan Persentase Pencapaian Tiap Indikator Siswa Kelas X2 SMA Negeri 1 Galesong Dengan Menggunakan pembelajaran kooperatif tipe "Examples Non Examples", pencapaian tiap indikator pada pembelajaran larutan elektrolit, non elektrolit dan reaksi redoks dapat pula dilihat pada gambar 1 dibawah ini :

\section{Presentase Ketuntasan Indikator \%}

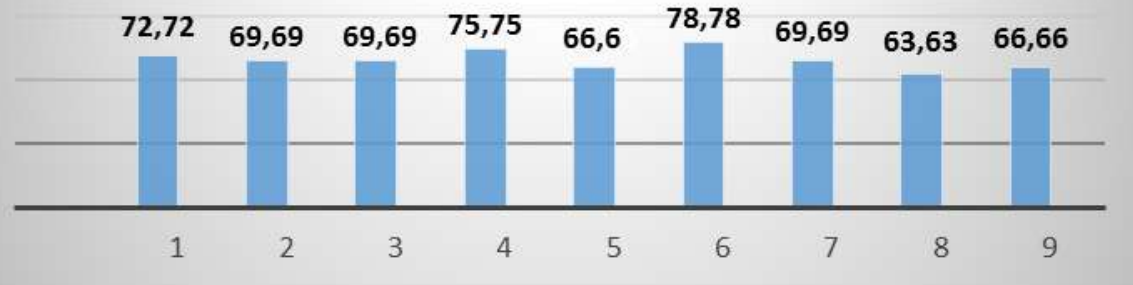

Gambar 1. Diagram Persentase Pencapaian Tiap Indikator Siswa Kelas X2 SMA Negeri 1 Galesong dengan Menggunakan pembelajaran kooperatif tipe "Examples Non Examples"

Ada beberapa komponen utama yang harus dipenuhi dalam proses pembelajaran yaitu siswa, pendidik, tujuan pembelajaran, metode pembelajaran, media dan evaluasi. Dari beberapa komponen ini sangat mempengaruhi tercapainya tujuan pembelajaran dalam proses pembelajaran. Dalam proses pembelajaran, ketika tujuan dari pembelajaran dapat dicapai secara tepat sesuai dengan tujuan pembelajaran yang telah ditentukan, maka suatu pembelajaran dapat dikatakan efektif. Ada banyak cara yang dapat dilakukan untuk mencapai suatu tujuan dalam pembelajaran, salah satunya yaitu melakukan terobosan baru dalam proses pembelajaran itu sendiri untuk meningkatkan kualitas pendidikan (Sani, 2013).

Pembelajaran Kooperatif tipe 'Examples Non Examples' adalah suatu proses pembelajaran yang dilakukan secara berkelompok dengan menggunakan "Examples Non Examples" (contoh dan bukan contoh). Contoh-contoh dapat diperoleh dari kasus/gambar yang relevan dengan kompetensi dasar. Dalam proses pembelajaran ini penggunaan media berupa gambar atau sebuah konsep yang berupa contoh dan non contoh harus di sesuiakan dengan materi yang akan diajarkan (Susanti, 2014).

Dalam proses pembelajaran dengan menggunakan model pembelajaran kooperatif tipe Examples Non Examples ini dilakukan dengan cara menampilkan gambar-gambar atau konsep yang relevan 
dengan materi yang diajarkan untuk mencapai suatu tujuan pembelajaran. Suatu proses pembelajaran yang menggunakan model pembelajaran kooperatif tipe Examples Non Examples ini dapat dilihat manfaat dan kekurangannya dengan melakukan penelitian yang dapat mengukur seberapa besar keefektifan pembelajaran menggunakan model pembelajaran kooperatif tipe Examples Non Examples yang diukur dengan menggunakan instrument hasil observasi siswa tiap pertemuan dan data hasil belajar siswa pada materi larutan elektrolit, non elektrolit dan reaksi redoks (Johar \& Hanum, 2016).

2. Analisis statistic deskriptif model pembelajaran kooperatif tipe examples non examples pada hasil belajar SMA Negeri 1 Galesong

Hasil analisis statistik deskriptif pada penelitian ini yang menggunakan model pembelajaran kooperatif tipe Examples Non Examples diperoleh hasil belajar siswa kelas X2 di SMA Negeri 1 Galesong diperoleh nilai tertinggi yaitu 92, nilai terendah yaitu 52 dan rata-rata nilai dari 33 siswa yaitu 81,45 dari nilai ideal yang diharapkan 100 . Dari hasil analisis deskriftif juga diperoleh siswa yang memenuhi kriteria ketuntasan $(\geq 70)$ yaitu sebanyak 29 orang atau dengan persentase ketuntasan yaitu $87,87 \%$. Sedangkan siswa yang tidak memenuhi kriteria ketuntasan $(<70)$ yaitu 4 orang atau dengan presentase $12,12 \%$ dan untuk ketuntasan kelas diperoleh $87,87 \%$ dari $100 \%$ tuntas kelas yang diharapkan.

Selain tuntas perorangan dan ketuntasan kelas ada juga pencapaian tuntas indicator yang diambil dari hasil analisis deskriktif hal ini dapat dilihat pada tabel 2. Pada tabel ini dapat dilihat jumlah presentase pencapaian indicator untuk tiap indikator.

Untuk indikator pertama yaitu mendefinisikan sifat larutan elektrolit dan non elektrolit dengan menampilkan media berupa gambar Examples Non Examples. Pada indikator yang pertama ini siswa yang tuntas yaitu sebanyak 24 orang dengan presentase $72,72 \%$. Pada indikator pertama ini dikategorikan efektif digunakan untuk pembahasan materi mendefenisikan larutan elektrolit dan non elektrolit. Pencapaian indikator yang diperoleh oleh siswa ini efektif. Dalam hal ini siswa menarik definisi dari larutan elektrolit dan non elektrolit dengan melihat gambar dari media yang ditampilkan. Untuk menarik sebuah kesimpulan siswa lebih mudah mendefinisikan dengan melihat gambar dengan atribut-atribut yang muncul pada media gambar yang berupa contoh dan non contoh.

Untuk indikator yang kedua yaitu mengelompokkan larutan kedalam larutan elektrolit dan non elektrolit berdasarkan sifat hantar listriknya memiliki jumlah siswa yang tuntas yaitu sebanyak 23 orang dengan presentase $69,69 \%$. Pada indikator kedua ini dikategorikan efektif. Hal ini dikarenakan karena soal tes hasil belajar yang diberikan memerlukan analisa yang tinggi untuk menjawab soal-soal tentang pengelompokan larutan elektrolit dan non elektrolit.

Untuk indikator yang ketiga yaitu menjelaskan penyebab kemampuan larutan elektrolit menghantarkan arus listrik. Pada indicator ini memiliki jumlah siswa yang tuntas yaitu 23 orang dengan presentase $69,69 \%$. Hasil ini menujukkan bahwa indicator yang ketiga ini dikategorikan efektif untuk menjelakan penyebab kemampuan larutan elektrolit menghantarkan arus listrik.

Dari ketiga indikator diatas, untuk data hasil observasi aktivitas siswa untuk pertemuan pertama yaitu 83,33. Hal ini menunjukkan bahwa nilai hasil observasi pada pertemuan pertama untuk tiga indicator cukup bagus karena dilihat dari indicator pertama, keduan dan ketiga saling berkaitan. Oleh karena itu siswa bisa lebih mudah memahami sebuah konsep dan menarik kesimpulan dalam proses pembelajaran.

Untuk indicator yang keempat yaitu mendeskripsikan bahwa larutan elektrolit dapat berupa senyawa ion dengan senyawa kovalen polar. Jumlah siswa yang tuntas pada indicator ini yaitu 25 orang dengan presentase ketuntasan $75,75 \%$. Hasil ini menunjukkan bahwa untuk mendeskripsikan larutan elektrolit dapat berupa senyawa ion dengan senyawa kovalen polar dikategorikan efektif digunakan untuk pembahasan pada indicator yang keempat.

Untuk indicator yang kelima yaitu mengelompokkan larutan elektrolit kuat, larutan lektrolit lemah dan non elektrolit ini memiliki jumlah ketuntasan yaitu 22 orang dengan presentase $66,66 \%$. Hasil ini dikategorikan efektif digunakan pada indicator mengelompokkan larutan elektrolit kuat, larutan elektrolit lemah dan non elektrolit. Hal ini disebabkan karena dalam soal tes hasil belajar siswa tidak bisa membedakan larutan yang termasuk elektrolit lemah dan non elektrolit pada inidikator yang kelima.

Untuk indikator yang keenam yaitu memahami peranan larutan elektrolit dan non elektrolit dalam ilmu kimia dan dalam kehidupan sehari-hari. Pada indicator ini jumlah siswa yang tuntas yaitu 26 orang dengan presentase ketuntasan yaitu 78,78\%. Pada indicator ini dikategorikan efektif digunakan untuk pemahaman larutan elektrolit dalam kehidupan sehari-hari dan dalam ilmu kimia. 
Dari ketiga indicator diatas diperoleh nilai hasil observasi aktivitas siswa yaitu 81,66. Hal ini menunjukkan bahwa aktivitas siswa dari ketiga indikator ini cukup baik. Dapat dilihat dari ke tiga indikator ini mulai dari indikator ke empat yaitu mendeskripsikan bahwa larutan elektrolit dapat berupa senyawa ion dengan senyawa kovalen polar, indikator ke lima yaitu mengelompokkan larutan elektrolit kuat, larutan lektrolit lemah dan non elektrolit dan indicator yang ke enam yaitu memahami peranan larutan elektrolit dan non elektrolit dalam ilmu kimia dan dalam kehidupan sehari-hari, menunjukkan bahwa aktivitas pada peretemuan ke dua cukup bagus karena indicator-indikator yang di ajarkan saling mendukung antara indikator yang satu dan indikator yang lain.

Untuk indikator yang ketujuh yaitu membedakan konsep reduksi ditinjau dari penerimaan dan pelepasan oksigen, penerimaan dan pelepasan electron, serta kenaikan dan penurunan bilangan oksidasi. Jumlah siswa yang tuntas yaitu 23 orang dengan presentase ketuntasan yaitu 69,69\%. Dari hasil yang diperoleh dikategorikan efektif pada indicator ketujuh. Untuk hasil observasi pada indicator ke tujuh ini menujukkan cukup baik, karena memperoleh nilai 80,00. Pada indicator ketujuh ini digunakan dua kali pertemuan dan nilai yang diperoleh untuk hasil observasi sama dengan pertemuan ketiga dan pertemuan ke empat yaitu 80,00.

Untuk indikator yang kedelapan yaitu menentukan bilangan oksidasi atom unsur dalam senyawa atau ion. Jumlah siswa yang tuntas yaitu 21 orang dengan presntase 63,63\%. Presentase ketuntasan yang di peroleh pada indicator ini disebabkan karena untuk menjawab soal-sola bilangan oksidasi dalam senyawa ion siswa diharapkan mengingat dengan baik aturan-aturan bilangan oksidasi. Hasil ini dikategorikan efektif digunakan. Dilihat dari hasil observasi pada indicator kedelapan ini untuk pertemuan ke lima yaitu 76,66. Hal ini menujukkan bahwa untuk indicator kedelapan ini siswa masih butuh meningkatkan penguasaan konsep pada indicator yang diajarkan.

Untuk indikator yang kesembilan yaitu menentukan oksidator dan reduktor dalam reaksi redoks. Pada indicator ini jumlah siswa yang tuntas yaitu 22 orang dengan presentase 66,66\%. Presentase ketuntasan yang diperoleh dikategorikan efektif. Hal ini di karenakan dalam menjawab soal siswa terkeco dengan reaksi redoks dan reaksi oksidasi yang menyamakan konsep dengan reduktor dan oksidator. Dilihat dari hasil observasi pada indicator kesembilan ini menujukkan nilai 80,00, untuk data hasil observasi siswa pada pertemuan ke enam ini dengan nilai yang diperoleh cukup baik.

Dalam pencapaian tuntas indicator dengan hasil observasi siswa, tidak sesuai hal ini dikarenakan dalam menarik sebuah kesimpulan dan sebuah konsep dalam proses pembelajaran dibutuhkankerjasama Antara kelompok dan saling memberikan sumbngsi pemikiran untuk menyimpulkan ataupun menraik sebuah konsep pada materi yang diajarkan. Sedangkan untuk mengukur tuntas indikator dilihat dari berapa siswa yang menjawab benar pada soal yang di ujicobakan setiap indicator.

Dilihat dari hasil pencapaian indikator dan ketuntasn siswa maka dapat diukur keefektifan model pembelajaran kooperatif tipe Examples Non Examples yaitu sebesar 70,36\% dari 100\% yang diharapkan. Dalam hal ini presentase keefektifan yang diperoelh memang bias dikatakan belum optimal hal ini dapat dilihat dari presentase ketuntasan tiap indicator. Ada beberapa indikator yang masih rendah presentase pencapaian ketuntasannya dapat dilihat pada tabel 4.3. Hal ini juga dapat dilihat dari hasil obeservasi siswa dalam proses pembelajaran yang menggunakan model pembelajaran kooperatif tipe Examples Non Exemples dalam tiap pertemuan mendapatkan rata-rata nilai 80,10. Hal ini dapat dilihat pada lampiran lembar observasi aktivitas siswa kelas X2 SMA Negeri 1 Galesong.

Selain ini dalam penelitian ini masih terdapat begitu banyak kekurangan contohnya, dalam proses pembelajaran masih ada siswa yang masih ribut saat pelajaran berlangsung, belum terjadi kerja sama yang baik antara anggota kelompok, ada siswa yang sulit untuk mempresentasekan hasil diskusinya, siswa juga masih malu bertanya dan menjawab pertanyaan guru, dan hanya beberapa siswa yang berperang aktif dalam menyampaika kesimpulan. Dalam hal ini yang menjadi kendala dalam proses pembelajaran koperatif tipe Examples Non Exemples yaitu susah mengontrol siswa yang dapat menganalisis gambar yang ditampilkan dan dalam proses pembelajaran yang berlangsung masih ada beberapa siswa yang rebut (Azar, 2011).

Adapun solusi yang dapat dilakukan untuk menangani kendala yang ditemukan dalam penelitian yang dilakukan untuk meningkatkan kualitas pembelajaran dengan menggunakan koperatif tipe Examples Non Examples yaitu lebih tegas kepada siswa sehingga tidak ada lagi siswa yang ribut, ngantuk dll dalam proses pembelajaran, memberikan bimbingan kepada semua kelompok serta arahan pada siswa dalam melaksanakan siskusi kelompok, mengarahkan dan membimbing siswa untuk menyimpulkan materi yang diajarkan.

Dalam penelitian ini selain kekurangan dan kendala yang masih terdapat dalam penelitian terdapat juga kelebihan yang dapat terlihat dari pengamatan oleh observer selama penelitian yaitu proses 
pembelajaran menjadi lebih menarik dengan menggunakan model examples non examples, siswa lebih termotivasi dalam belajar karena menggunakan gambar, siswa kritis dalam menganalisi gambar, dan siswa juga bebas mengemukakan pendapatnya dalam proses pembelajarana (Arnyana, 2006).

Hasil yang diperoleh dalam penelitian ini sesui dengan penelitian yang dilakukan oleh (Arafat, Dinan, Akbar, \& Haseeb, 2012) yang melakukan penelitian mengenai pengaruh model pembelajaran kooperatif tipe Examples Non Examples terhadap hasil belajar siswa pada materi ikatan kimia. Pada penelitian yang dilakukan oleh Akbar menemukan bahwa melalui model pembelajaran kooperatif tipe Examples Non Examples yaitu (1) memiliki pengaruh positif terhadap peningkatan hasil belajar siswa pada materi ikatan kimia, (2) meningkatkan motivasi siswa dengan menggunakan model pembelajaran kooperatif tipe Examples Non Examples dari pada pembelajaran konvensional.

Penelitian yang lain dilakukan oleh (Astuti \& Setiawan, 2013) mengenai keefektifan model pembelajaran kooperatif tipe Examples Non Examples untuk meningkatkan hasil belajar pada materi koloid menemukan bahwa (1) hasil belajar yang diperoleh pada materi koloid dengan menggunakan model pembelajaran kooperatif tipe Examples Non Examples lebih tinggi dari pada pembelajaran konfensional dan (2) pemahaman konsep yang diperoleh siswa lebih tinggi.

\section{Kesimpulan}

Berdasarkan hasil analisis data penelitian dan pembahasan dapat disimpulkan bahwa rata - rata nilai siswa untuk materi larutan elektrolit, non elektrolit dan reaksi oksidasi reduksi yaitu 81,45 dengan tuntas kelas sebesar 87,87. Adapun keefektifan model pembelajaran kooperatif tipe Examples Nom Examples yang ditinjau dari hasil belajar siswa kelas X2 di SMA Negeri 1 Galesong pada materi pokok larutan elektrolit, non elektrolit dan reaksi oksidasi reduksi yaitu sebesar 70,36\%.

Berdasarkan pengalaman peneliti selama melaksanakan penelitian di SMA Negeri 1 Galesong, peneliti mengajukan beberapa saran yaitu:

1. Diharapkan guru bidang studi kimia mempertimbangkan penerapan pembelajaran dengan menggunakan model pembelajaran kooperatif tipe Examples Non Examples dalam pembelajaran dengan tetap memperhatikan kesesuaian dengan materi pelajaran yang akan diajarkan dan lebih memperhatikan waktu yang digunakan agar dalam proses pembelajaran tidak menggunakan waktu yang terlalu banyak,

2. Dalam melakukan model pembelajaran kooperatif tipe Exemples Non Exemples sebaiknya lebih memfokuskan siswa sebelum memulai pembelajaran, mengarahkan siswa dalam menganalisis gambar dan mengarahkan siswa dalam menyimpulakan pelajaran

3. Kepada penelitian selanjutnya yang ingin mengkaji penelitian yang sama agar lebih memperdalam penguasaan mengenai model pembelajaran kooperatif tipe Examples Non Examples yang menggunakan media berupa gambar atau konsep. Dalam hal ini model pembelajaran kooperatif tipe Examples Non Examples juga bisa menggunakan media lain selain gambar contohnya alat peraga, media berupa konsep, dll

\section{Referensi}

Arafat, M. M., Dinan, B., Akbar, S. A., \& Haseeb, A. (2012). Gas sensors based on one dimensional nanostructured metal-oxides: a review. Sensors, 12(6), 7207-7258.

Arnyana, I. B. P. (2006). Pengaruh Penerapan Strategi Pembelajaran Inovatif pada pelajaran biologi terhadap kemampuan berpikir kreatif siswa SMA. Jurnal Pendidikan Dan Pengajaran IKIP Negeri Singaraja, 3(6), 496-515.

Astuti, Y., \& Setiawan, B. (2013). Pengembangan lembar kerja siswa (LKS) berbasis pendekatan inkuiri terbimbing dalam pembelajaran kooperatif pada materi kalor. Jurnal Pendidikan IPA Indonesia, 2(1).

Azar, A. (2011). Media pembelajaran. Evaluasi Pembelajaran, Dsb), Dan.

Hutabalian, T. (2014). Pengembangan Buku Ajar Kimia Inovatif Kelas X SMA Semester I Sesuai Kurikulum 2013. UNIMED.

Johar, R., \& Hanum, L. (2016). Strategi Belajar Mengajar. Deepublish.

Marsita, R. A., Priatmoko, S., \& Kusuma, E. (2010). Analisis kesulitan belajar kimia siswa SMA dalam memahami materi larutan penyangga dengan menggunakan two-tier multiple choice diagnostic instrument. Jurnal Inovasi Pendidikan Kimia, 4(1). 
Ningrum, E. (2009). Pendekatan Kontekstual (Contextual Teaching and Learning). In Makalah Disajikan Dalam Pelatihan Dan Workshop Model-Model Pembelajaran Dalam Persiapan Rsbi Di Kabupaten Karawang.

Patmawati, H. (2011). Analisis keterampilan berpikir kritis siswa pada pembelajaran larutan elektrolit dan non elektrolit dengan metode praktikum.

Roestiyah, N. K. (2008). Metode Belajar Mengajar. Jakarta: Rineka Cipta.

Rusman. (2011). Model-model pembelajaran: mengembangkan profesionalisme guru. Rajawali Pers/PT Raja Grafindo Persada.

Sani, R. A. (2013). Inovasi pembelajaran. Jakarta: Bumi Aksara.

Susanti, R. (2014). Pembelajaran Model Examples Non Examples Berbantuan Powerpoint Untuk Meningkatkan Hasil Belajar IPA. Jurnal Pendidikan IPA Indonesia, 3(2).

Tjalla, A. (2010). Potret mutu pendidikan indonesia ditinjau dari hasil-hasil studi internasional.

Yensy, N. A. (2012). Penerapan model pembelajaran kooperatif tipe examples non examples dengan menggunakan alat peraga untuk meningkatkan hasil belajar siswa di kelas VIII SMP N 1 Argamakmur. Exacta, 10(1), 24-35. 